(c) American Dairy Science Association, 2004.

\title{
Mapping Quantitative Trait Loci Affecting Dairy Conformation to Chromosome 27 in Two Holstein Grandsire Families
}

\author{
C. P. Van Tassell, T. S. Sonstegard, and M. S. Ashwell \\ Bovine Functional Genomics Laboratory, \\ Agricultural Research Service, \\ USDA, Beltsville, MD 20705
}

\section{ABSTRACT}

Preliminary marker association results for quantitative trait loci affecting conformation traits using the granddaughter design and 8 large US Holstein grandsire families revealed strong associations in two families between the predicted transmitting abilities for dairy conformation and marker genotypes on bovine chromosome 27. Those results were based on single marker-trait associations in a genome-scan to identify broad chromosomal regions potentially containing genes affecting traits of interest. Results presented here describe continued study of quantitative trait loci on chromosome 27 for eventual incorporation into a marker-assisted selection program. Tests of marker associations for family 8 (91 sons) indicated an association with a microsatellite marker located near the telomere of chromosome 27. Interval analysis performed using additional marker genotypes generated for family 8 yielded further evidence for a quantitative trait locus in this region. No evidence was found for associations with milk production traits in this family in this region. An association was also detected in family 2 (240 sons) with a microsatellite marker located approximately 21 $\mathrm{cM}$ from the centromere of chromosome 27. Interval analysis performed for family 2 yielded evidence for a quantitative trait locus for dairy conformation near BMS689 with evidence of associations with fat percentage in the same region. Identification of quantitative trait loci affecting dairy conformation and fat components supports results reported by other groups, providing additional evidence that genes affecting fat metabolism are located on bovine chromosome 27.

(Key words: quantitative trait loci, dairy cattle, dairy conformation)

Abbreviation key: BTA27 = Bos taurus autosome 27, DBDR = Dairy Bull DNA Repository, DF = dairy conformation.

Received April 11, 2003.

Accepted August 10, 2003.

Corresponding author: C. P. Van Tassell; e-mail: curtvt@anri. barc.usda.gov.

\section{INTRODUCTION}

Although selection to improve milk production has been effective using traditional methods, the rate of improvement could be increased using marker-assisted selection. Furthermore, traditional methods of selection have difficulty improving lowly heritable traits, such as reproduction and disease resistance. It is estimated that mastitis alone costs dairy producers $\$ 2$ billion annually (Eberhart et al., 1987). Thus, application of marker-assisted selection for these traits and others, like reproduction, length of productive life and conformation traits associated with fitness, would increase the rate of genetic improvement over a broader range of traits. However, before marker-assisted selection can be implemented, QTL must be identified and characterized first.

Detection of allelic variation at loci affecting economically important traits for cattle has become feasible in recent years, with the production of linkage maps composed of mostly microsatellite markers (Barendse et al., 1994; Bishop et al., 1994; Barendse et al., 1997; Kappes et al., 1997). A genome-scan study was initiated in 1994 to identify QTL affecting economically important traits such as milk production, SCS, calving ease, and conformation traits in an existing US Holstein population consisting of 8 large families from the Dairy Bull DNA Repository (DBDR; Da et al., 1994). The genome-scan of these 8 families was recently completed (Ashwell et al., 2001) and identified many putative QTL affecting traits such as protein percentage, fat percentage, fat yield, SCS, rump angle, feet and leg traits, and dairy conformation (DF).

The next step towards implementing marker-assisted selection is to refine the estimates of QTL effects and map positions. The first putative marker-trait association we selected for further study was a highly significant association between BM203 on Bos taurus autosome 27 (BTA27) and the conformation trait, DF, detected in one DBDR family (Ashwell et al., 1998). More recently, an additional association between BMS1385 (located in a different region of BTA27) and DF was detected in a second DBDR family (Ashwell et al., 2001). 
The goal of this project was to refine the location of the putative QTL affecting DF and estimate the magnitude of the substitution effects. In addition, the relationship of these QTL effects to milk production traits was also of interest to assess the potential impact on production if this QTL was to be used in a marker assisted selection program.

\section{MATERIALS AND METHODS}

\section{Source of Materials}

Eight Holstein grandsire families were originally selected from the DBDR (Da et al., 1994) for the genomescan. DNA extraction and PCR amplification protocols were previously described (Ashwell et al., 1996; Ashwell et al., 1997). For this project, the same DNA samples from DBDR families 2 and 8 used in the genome scan (Ashwell et al., 2001) were again studied to refine the location of the putative DF QTL. Phenotypic data for milk yield and composition, SCS, and productive life were collected through DHIA and processed as part of the routine February 2003 genetic evaluation procedure by the Animal Improvement Programs Laboratory of ARS. The Holstein Association USA (2003) provided February 2003 genetic evaluations for conformation traits.

\section{Map Refinement}

For the original genome-scan, markers were selected from the USDA bovine linkage maps (Bishop et al., 1994; Kappes et al., 1997) for an average of $20 \mathrm{cM}$ coverage. For QTL location refinement, additional markers were selected from the USDA map (http:// www.marc.usda.gov) for study in DBDR families 2 and 8. In addition, microsatellite markers developed from research to build a BTA27 comparative map (Sonstegard et al., 2000) were included. Approximately 40 markers were evaluated, including some ovine markers. In the end, a total of 22 markers were useful for the current study. The Casas et al. (2001) study was used to determine map location, because all of the markers considered in this study were included in that map. Casas et al. (2001) produced a consensus map that included data from a number of research groups, including the USDA data. Genotyping additional markers in the regions would be useful. However, only 26 microsatellite markers are currently available on the USDA map for BTA27 with assigned positions. An additional 12 markers have unknown positions. A total of 39 microsatellites are presently placed on the Institut National de Recherche Agronomique map. An additional 26 loci associated with genes are present on that map, and many of them are a result of the comparative effort conducted by this group (Sonstegard et al., 2000). These gene-associated loci were not tested because they were expected to be uninformative in a pure Holstein population, as the polymorphisms used to map these loci were not derived from Holsteins. A draft sequence of the bovine genome would greatly simplify marker development in cattle, especially on the telomeric end of BTA27, where evidence exists for an evolutionary break between human and cattle (Sonstegard et al., 2000).

\section{Data Validation}

Probability of inheritance of the maternal or paternal allele from the grandsire to son was calculated for each son across the length of the chromosome considered in both families. These probabilities are similar to the Chrompic output generated by CRI-Map (Lander and Green, 1987; Green et al., 1990). These probabilities were plotted to subjectively evaluate data quality and to identify suspect genotypes for validation. Additionally, before further analyses were done, the genotypes were evaluated to identify problematic inheritances. Wherever a double crossover event appeared to include only a single marker, that particular animal's DNA was reamplified for that marker and scored. Furthermore, marker genotypes for a son that indicated a crossover for the terminal marker of the linkage group were reanalyzed. This process was repeated until the recombinations were confirmed or problem genotypes were corrected.

\section{Statistical Analyses}

For our studies described here, interval analysis for informative markers on BTA27 for each family was conducted using a regression approach originally described by Haley and Knott (1992). A web-based version of this regression interval mapping method is now available (Seaton et al., 2002). The software, entitled QTL Express (http://qtl.cap.ed.ac.uk), analyzes data from $\mathrm{F}_{2}$, half-sib, and sib-pair families to detect QTL. The software allows the user to fit one and two QTL and includes tools for permutation and bootstrap analyses to calculate chromosome-wise significance thresholds and $95 \%$ confidence intervals, respectively. For this study, 1000 permutations were studied for each trait to determine the chromosome-wise significance thresholds. One thousand resamples were selected for bootstrapping to determine the $95 \%$ confidence intervals, and the regression interval analysis was conducted at 1-cM intervals along the chromosome. For this study, standardized transmitting ability for DF and daughter yield deviations for production traits were analyzed, weighted using their respective reliabilities. Linkage 
analyses were done within the two original DBDR families.

\section{RESULTS AND DISCUSSION}

In previous reports related to the genome scan (e.g., Van Tassell et al., 2000; Ashwell et al., 2001), a singlemarker approach was used to analyze data to identify suggestive marker-QTL associations. Based on the highly significant ANOVA results for BM203 from this work (Ashwell et al., 1998), additional markers from the USDA BTA27 linkage map were genotyped in grandsires from DBDR families 2 and 8 to initiate refinement of the location and the magnitude of QTL for DF on this chromosome.

Dairy conformation phenotypic scores are based to a large extent upon the "dairyness" of a cow, which includes body condition and characteristics of the slope and openness of the ribs. The linear trait DF has intermediate heritability, estimated at approximately 0.28 and is moderately correlated with milk production (Misztal et al., 1995), meaning that as cows increase in milk production they tend to appear more dairy and less fat.

Rogers et al. (1999) studied the genetic correlations among protein yield, productive life and type traits and 3 groups of diseases: reproductive, foot and leg and metabolic and digestive diseases. Results from the study found that correlations of most type traits with the diseases were small and unimportant. However, the genetic correlations between DF and the 3 disease categories were negative and moderate in magnitude (Rogers et al., 1999). Currently some selection in the United States is towards increased DF, and this trait is used to help select bull dams. Therefore selection for increased DF may lead to cows that are more prone to reproductive and metabolic diseases (Rogers et al., 1999).

Development of genetic markers for selection of DF QTL would be beneficial to producers for breeding cattle less susceptible to reproductive and metabolic disease, if selection paralleled the genetic correlations between disease incidence and extreme dairyness. To date, the economic value of $\mathrm{DF}$ with respect to increased productive life has not been well established. However, identification of genes underlying DF QTL would help elucidate the genetic and physiological mechanisms of fat metabolism in dairy cattle.

Fourteen of 22 markers selected from the linkage map (Table 1) were heterozygous in DBDR grandsire 8. Regression interval analysis was first completed fitting one QTL in the model. Results provided strong evidence (LOD score $=3.47$ ) of a QTL affecting DF near marker BM203 in family 8 (Figure 1; Table 2). The bootstrap analyses yielded a $95 \%$ confidence interval of 12.5 to
Table 1. Marker location and heterozygosity of the grandsires for each family on BTA27.

\begin{tabular}{llll}
\hline Marker & $\begin{array}{l}\text { Relative } \\
\text { location }(\mathrm{cM})^{1}\end{array}$ & $\begin{array}{l}\text { DBDR } \\
\text { family } 2\end{array}$ & $\begin{array}{l}\text { DBDR } \\
\text { family 8 }\end{array}$ \\
\hline BM3507 & 0.9 & $\overline{-}^{2}$ & $\mathrm{H}$ \\
TGLA179 & 7.7 & $\mathrm{H}$ & $\mathrm{N}$ \\
BM871 & 10.6 & $\mathrm{H}$ & $\mathrm{H}$ \\
BB716 & 17.6 & $\mathrm{H}$ & $\mathrm{H}$ \\
CA209 & 18.7 & $\mathrm{H}$ & $\mathrm{H}$ \\
INRA016 & 21.7 & $\mathrm{~N}$ & $\mathrm{H}$ \\
BMS2137 & 24.4 & $\mathrm{H}$ & $\mathrm{H}$ \\
INRABERN191 & 24.9 & $\mathrm{~N}$ & $\mathrm{H}$ \\
BMS1385 & 26.7 & $\mathrm{H}$ & $\mathrm{N}$ \\
BMS689 & 37.2 & $\mathrm{H}$ & $\mathrm{H}$ \\
CSSM36 & 44.5 & $\mathrm{~N}$ & $\mathrm{~N}$ \\
INRA134 & 47.6 & $\mathrm{~N}$ & $\mathrm{~N}$ \\
BB708 & 47.7 & $\mathrm{~N}$ & $\mathrm{~N}$ \\
BM1857 & 52.6 & $\mathrm{H}$ & $\mathrm{H}$ \\
BMS2116 & 54.9 & $\mathrm{H}$ & $\mathrm{H}$ \\
MSBQ & 56.0 & $\mathrm{H}$ & $\mathrm{N}$ \\
BB700 & 58.7 & $\mathrm{H}$ & $\mathrm{H}$ \\
BB701 & 58.7 & $\mathrm{~N}$ & $\mathrm{H}$ \\
INRA027 & 70.5 & $\mathrm{H}$ & $\mathrm{H}$ \\
BM17052 & 71.2 & - & $\mathrm{N}$ \\
BMS1675 & 75.5 & - & $\mathrm{H}$ \\
BM203 & 75.5 & $\mathrm{H}$ & $\mathrm{H}$ \\
\hline
\end{tabular}

${ }^{1}$ Relative location of markers on consensus linkage map (Casas et al., 2001).

${ }^{2}$ Grandsire in family is heterozygous (H), homozygous (N), or not genotyped (-).

$74 \mathrm{cM}$, although approximately $70 \%$ of the bootstrap results were near the telomere of BTA27 (>70 cM; results not shown). The estimate of the difference of allelic effect for the putative QTL from the regression analysis was $0.91( \pm 0.22)$ units (i.e., genetic standard deviations). Because BM203 is the most distal marker on the linkage map, the QTL is not flanked. Additional markers are needed distal to BM203 to bracket the interval and to further refine the estimates of location and magnitude of the putative QTL. Work to identify bacterial artificial chromosome clones from this region is underway. Isolation and subcloning of those clones should identify new microsatellites that will be tested for heterozygosity in family 8. A draft sequence of the bovine genome would greatly simplify marker development in this region. This region corresponds to human chromosome $8 \mathrm{p}$ at approximately $60 \mathrm{cM}$ based on the human transcript map (Sonstegard et al., 2000); however, no obvious positional candidate genes were identified.

There was evidence for QTL affecting all 3 yield traits with LOD scores ranging from 1.5 to 1.8 and $P<0.05$ based on permutation tests (Table 2). The QTL were all estimated to be located at $21 \mathrm{cM}$, near marker INRA016. There was no evidence of QTL for productive life, SCS, or the milk component traits on BTA27 in family 8 with LOD scores $<0.6$ and $P>0.05$ (Table 2). 


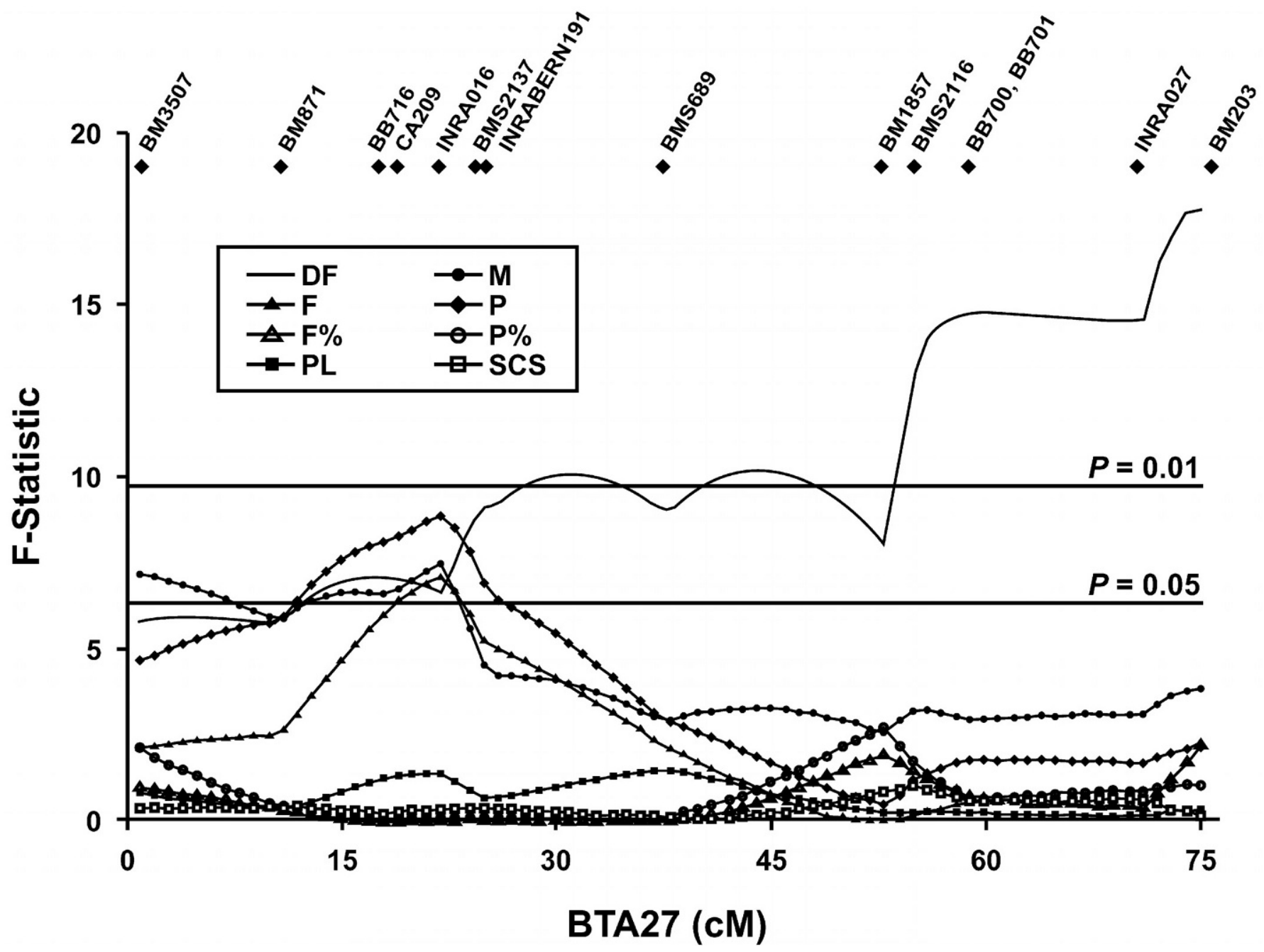

Figure 1. Interval map for DBDR family 8, fitting one QTL in the model. Traits evaluated include the standardized transmitting ability for dairy conformation (DF), daughter yield deviations for milk yield (M), fat yield (F), protein yield (P), percent fat $(\mathrm{F} \%)$, percent protein $(\mathrm{P} \%)$, productive life (PL), and SCS. Informative marker locations are shown as diamonds.

The QTL associated with yield traits should segregate independently, because the distance between the two QTL exceeds $50 \mathrm{cM}$. To evaluate the impact of selection at the putative QTL locus in this family, marker effects were estimated at the location of the putative DF QTL (74 cM). There was no evidence of any other QTL in this region (Table 2), with all LOD scores $<1$. Despite lack of significance, marker effect estimates were of interest to assess the potential impact of selection for the desired QTL on other traits. The DF QTL estimated substitution effect is over $90 \%$ of a genetic standard deviation compared to less than $50 \%$ for milk yield and approximately $25 \%$ for protein yield. This discrepancy in magnitude should allow for index selection to alter DF without significant loss in milk or component yield.
The data were also analyzed fitting 2 QTL in the model (Table 3). For the majority of the traits, the estimated locations for the two QTL were quite close together. In all cases, the estimated substitution effects were opposite in sign and of similar magnitude. In most cases the magnitude of these estimated effects were also unreasonably large, with estimates as much as 16 times the single locus model solutions, and as large as 10 genetic standard deviations. None of the traits showed significant improvements in model fits when a second QTL was added $(P>0.05)$. The two QTL model results were concluded to be spurious in this family.

The same approach was used to study DBDR family 2 . From previous work (Ashwell et al., 2001), a significant association between DF and marker BMS1385 on BTA27 had been identified. Thirteen of the 19 markers 
Table 2. F-statistics, degrees of freedom (df), approximate likelihood ratio (LR) test statistics, estimates of marker effects for dairy conformation and production traits at the location on the chromosome where each trait was most significant in family 8 and where dairy conformation test statistic was maximized (74 cM), fitting one QTL in the model.

\begin{tabular}{|c|c|c|c|c|c|c|c|c|c|c|}
\hline \multirow[b]{3}{*}{ Trait } & \multirow[b]{3}{*}{$\mathrm{df}$} & \multicolumn{5}{|c|}{ Chromosome maximum } & \multicolumn{4}{|c|}{ Dairy conformation maximum $(74 \mathrm{cM})$} \\
\hline & & \multirow[b]{2}{*}{ F-statistic ${ }^{1}$} & \multirow[b]{2}{*}{ LR } & \multirow{2}{*}{$\begin{array}{l}\text { Location } \\
(\mathrm{cM})\end{array}$} & \multicolumn{2}{|c|}{ Marker effect } & \multirow[b]{2}{*}{ F-statistic ${ }^{1}$} & \multirow[b]{2}{*}{$\mathrm{LR}$} & \multicolumn{2}{|c|}{ Marker effect } \\
\hline & & & & & Estimate $^{2}$ & SE & & & Estimate $^{2}$ & SE \\
\hline Dairy conformation & 81 & $17.8^{* *}$ & 16.0 & 74 & 0.91 & 0.22 & & & & \\
\hline Milk yield & 89 & $7.5^{*}$ & 7.1 & 21 & 161 & 59 & 3.8 & 3.7 & 130 & 67 \\
\hline Fat yield & 89 & $7.1^{*}$ & 6.8 & 21 & 6.2 & 2.3 & 0.1 & 0.1 & 0.7 & 2.7 \\
\hline Fat percent & 89 & 2.1 & 2.2 & 74 & -4.2 & 2.8 & 2.2 & 2.2 & -4.2 & 2.8 \\
\hline SCS & 74 & 1.0 & 1.0 & 54 & -4.3 & 4.4 & 0.1 & 0.1 & -1.4 & 4.7 \\
\hline Productive life & 89 & 1.4 & 1.4 & 37 & 4.4 & 3.7 & 0.3 & 0.3 & 2.7 & 4.0 \\
\hline
\end{tabular}

$*=P<0.05$.

$* *=P<0.01$

${ }^{1} \mathrm{~F}$-statistics significance based on 1000 permutations.

${ }^{2}$ Units of marker effect estimates: dairy conformation as units of genetic standard deviation; daughter yield deviation for milk, fat, protein yield reported in kg; SCS adjusted to log base 2 of the concentration; protein and fat percents reported as \% of protein or fat yield/milk yield; productive life reported as months of life.

(Table 1) selected from the BTA27 linkage map were heterozygous in grandsire 2 and genotyped in the sons. Regression interval analysis was completed fitting one QTL, providing moderate evidence for a QTL affecting DF near BMS689 at $40 \mathrm{cM}$ (Figure 2), with a 95\% confidence interval from 27 to $52 \mathrm{cM}$. The estimate of the difference of allelic effect for this putative QTL was $0.44( \pm 0.13)$ genetic standard deviations (Table 4). Unfortunately, there is a paucity of informative markers in this region, with a distance of over $15 \mathrm{cM}$ between the informative markers that flank the region. This region of BTA27 is orthologous to human chromosome 4q; from approximately $160 \mathrm{cM}$ to the telomere (Sonstegard et al., 2000). No positional candidate genes have been identified due to the lack of comparative assignments between the human and cattle maps in this region. Work is currently underway to develop a compara- tive map of this region of BTA27 and identify new microsatellite markers that can be used to genotype DBDR family 2 . These new markers will allow more refined estimates of location and magnitude of the putative QTL in this family.

With the exception of fat percentage, when fitting one QTL in the model, there is very little evidence for QTL associated with production traits on this chromosome, with LOD scores ranging from 0.26 to 0.65 (Table 4). There was evidence for QTL affecting fat percentage with a LOD score of 1.72 and a $P$-value of approximately 0.01 based on permutation tests (Table 4 ). The estimated substitution effect was $6.2 \%( \pm 2.3 \%)$ at $46 \mathrm{cM}$ with a $95 \%$ confidence interval from 17 to $61 \mathrm{cM}$.

When examining the effect on production traits, SCS, or PL at the location where the test for DF QTL is most significant, only fat percentage is significant (Table 4).

Table 3. Approximate likelihood ratio (LR) test statistics and estimated locations and effects of QTL in family 8, fitting a two QTL model.

\begin{tabular}{|c|c|c|c|c|c|}
\hline \multirow[b]{2}{*}{ Trait } & \multirow[b]{2}{*}{ LR } & \multicolumn{2}{|c|}{ QTL1 } & \multicolumn{2}{|c|}{ QTL2 } \\
\hline & & $\begin{array}{l}\text { Location } \\
\text { (cM) }\end{array}$ & Estimate $^{1}$ & $\begin{array}{l}\text { Location } \\
\text { (cM) }\end{array}$ & Estimate $^{1}$ \\
\hline Dairy conformation & 18.6 & 53 & -4.3 & 54 & 5.1 \\
\hline Milk yield & 9.4 & 23 & 1050 & 25 & -919 \\
\hline Fat yield & 8.8 & 17 & -50 & 19 & 54 \\
\hline Fat percent & 4.8 & 54 & -24 & 61 & 22 \\
\hline Protein yield & 10.3 & 24 & 77 & 25 & -74 \\
\hline Protein percent & 7.2 & 2 & -12 & 11 & 10 \\
\hline SCS & 3.2 & 31 & 9.5 & 54 & -10.4 \\
\hline Productive life & 2.3 & 23 & 45 & 24 & -42 \\
\hline
\end{tabular}

${ }^{1}$ Units of marker effect estimates: dairy conformation as units of genetic standard deviation; daughter yield deviation for milk, fat, protein yield reported in kg; SCS adjusted to log base 2 of the concentration; protein and fat percents reported as \% of protein or fat yield/milk yield; productive life reported as months of life. 


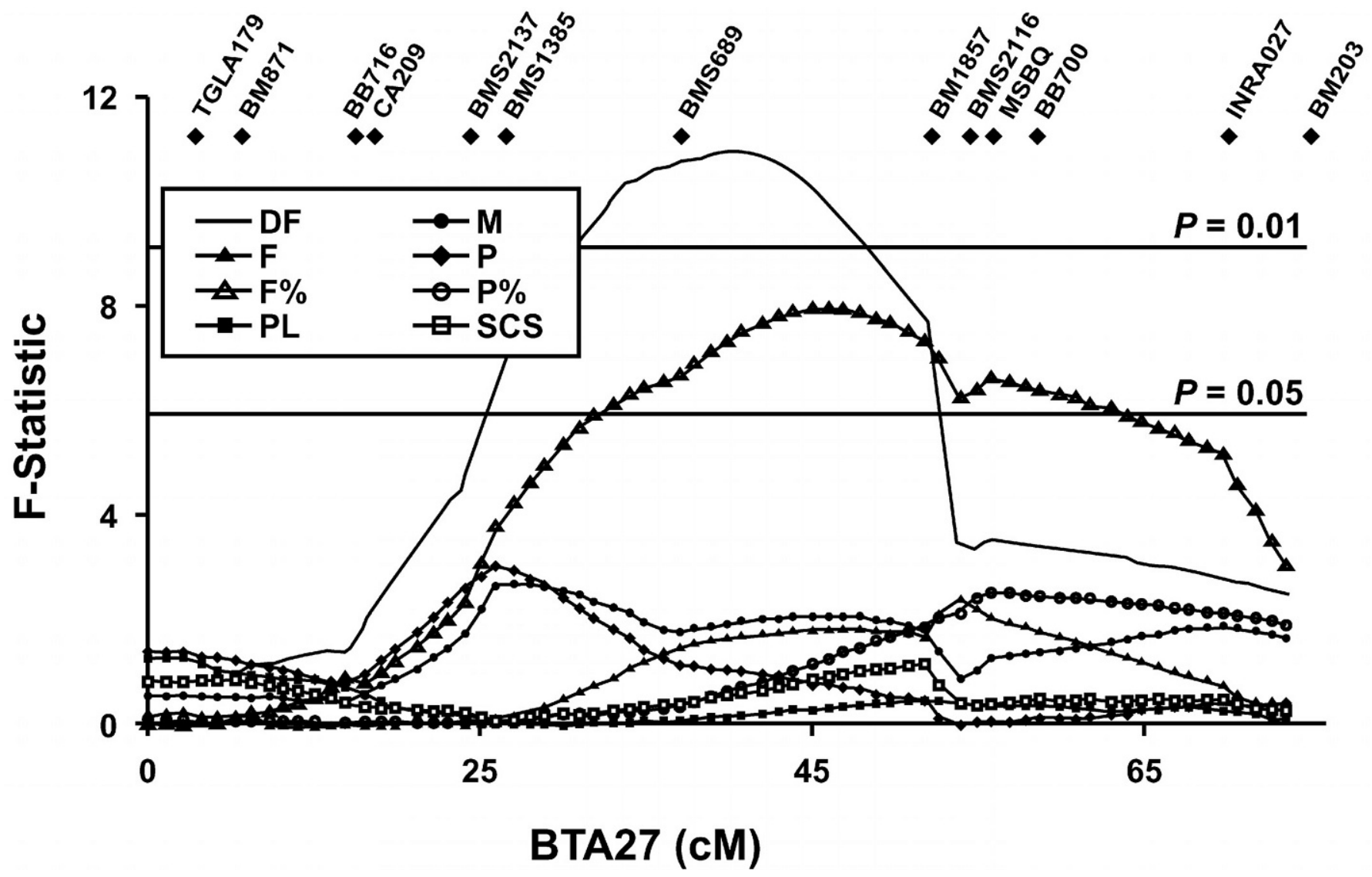

Figure 2. Interval map for DBDR family 2, fitting one QTL in the model. Traits evaluated include the standardized transmitting ability for dairy conformation (DF), daughter yield deviations for milk yield (M), fat yield (F), protein yield (P), percent fat (F\%), percent protein $(\mathrm{P} \%)$, productive life (PL), and SCS. Informative marker locations are shown as diamonds.

Table 4. F-statistics, degrees of freedom (df), approximate likelihood ratio (LR) test statistics, estimates of marker effects for dairy conformation and production traits at the location on the chromosome where each trait was most significant in family 2 and where dairy conformation test statistic was maximized (40 cM), fitting one QTL in the model.

\begin{tabular}{|c|c|c|c|c|c|c|c|c|c|c|}
\hline \multirow[b]{3}{*}{ Trait } & \multirow[b]{3}{*}{$\mathrm{df}$} & \multicolumn{5}{|c|}{ Chromosome maximum } & \multicolumn{4}{|c|}{ Dairy conformation maximum (40 cM) } \\
\hline & & \multirow[b]{2}{*}{ F-statistic ${ }^{1}$} & \multirow[b]{2}{*}{ LR } & \multirow{2}{*}{$\begin{array}{l}\text { Location } \\
(\mathrm{cM})\end{array}$} & \multicolumn{2}{|c|}{ Marker effect } & \multirow[b]{2}{*}{ F-statistic ${ }^{1}$} & \multirow[b]{2}{*}{ LR } & \multicolumn{2}{|c|}{ Marker effect } \\
\hline & & & & & Estimate $^{2}$ & $\mathrm{SE}$ & & & Estimate $^{2}$ & SE \\
\hline Dairy conformation & 240 & $11.0 * *$ & 10.7 & 40 & 0.44 & 0.13 & & & & \\
\hline Milk yield & 238 & 2.7 & 2.7 & 27 & 62 & 38 & 1.9 & 1.9 & 53 & 38 \\
\hline Fat yield & 238 & 2.4 & 2.4 & 54 & -2.0 & 1.3 & 1.7 & 1.7 & 1.8 & 1.4 \\
\hline Fat percent & 238 & $8.0^{*}$ & 7.9 & 46 & -3.7 & 1.3 & $7.4^{*}$ & 7.3 & -3.5 & 1.3 \\
\hline SCS & 238 & 1.2 & 1.2 & 52 & 2.8 & 2.6 & 0.5 & 0.5 & 2.0 & 2.7 \\
\hline Productive life & 238 & 1.3 & 1.3 & 6 & -3.2 & 2.8 & 0.1 & 0.1 & -1.0 & 2.7 \\
\hline
\end{tabular}

$*=P<0.05$.

$* *=P<0.01$.

${ }^{1} \mathrm{~F}$-statistics significance based on 1000 permutations.

${ }^{2}$ Units of marker effect estimates: dairy conformation as units of genetic standard deviation; daughter yield deviation for milk, fat, protein yield reported in kg; SCS adjusted to log base 2 of the concentration; protein and fat percents reported as \% of protein or fat yield/milk yield; productive life reported as months of life. 
Table 5. Approximate likelihood ratio (LR) test statistics and estimated locations and effects of QTL in family 2, fitting a two QTL model.

\begin{tabular}{|c|c|c|c|c|c|}
\hline \multirow[b]{2}{*}{ Trait } & \multirow[b]{2}{*}{ LR } & \multicolumn{2}{|c|}{ QTL1 } & \multicolumn{2}{|c|}{ QTL2 } \\
\hline & & Location (cM) & Estimate $^{1}$ & Location (cM) & Estimate $^{1}$ \\
\hline Dairy conformation & 17.8 & 46 & 1.39 & 54 & -0.96 \\
\hline Milk yield & 5.6 & 21 & -215 & 26 & 264 \\
\hline Fat yield & 10.1 & 55 & -11 & 74 & 11 \\
\hline Fat percent & 11.2 & 63 & -14 & 74 & 11 \\
\hline Protein yield & 5.2 & 17 & -3.4 & 25 & 4.8 \\
\hline Protein percent & 3.8 & 24 & 0.9 & 56 & -1.4 \\
\hline SCS & 2.3 & 52 & 18 & 53 & -16 \\
\hline Productive life & 5.2 & 6 & -992 & 7 & 973 \\
\hline
\end{tabular}

${ }^{1}$ Units of marker effect estimates: dairy conformation as units of genetic standard deviation; daughter yield deviation for milk, fat, protein yield reported in kg; SCS adjusted to log base 2 of the concentration; protein and fat percents reported as \% of protein or fat yield/milk yield; productive life reported as months of life.

It is interesting to note, however, that in family 2 the nonsignificant effects associated with the location where DF is most significant indicate that improvements in all yield traits would be realized if selection was applied to reduce DF, while reduction would result in component traits, particularly fat percentage.

The data from family 2 were also analyzed fitting a two QTL model (Table 5). Many of the estimated locations in these analyses resulted in one of the QTL locations being at or near the single QTL model estimated location. The majority of these results showed nonsignificant $(P>0.05)$ improvements in LR tests comparing improvement over single QTL model results. Like in family 8, in every case, the sign of the estimated QTL effects were opposite and the magnitudes of QTL effects were similar.

A substantial improvement in the LR test statistic is seen for the QTL model fit for DF, but neither estimated location is in common with the single QTL location, so a LR test cannot be used. However, based on Akaike's (1974) information content, the two QTL model had a lower score and is considered more parsimonious and, therefore, more appropriate. The estimated QTL locations are quite close together, with only $8 \mathrm{cM}$ separating them. The magnitudes of the estimated effects are also very large, especially when compared to the single QTL model estimate. Further refinement of DF QTL is clearly needed in this family.

Evidence for 2 QTL was identified for fat yield and fat percent as well, based on approximate chi-square tests of the LR test statistic $(P<0.05)$. It should be noted that no evidence for QTL exists for fat yield when fitting only a single QTL. Evidence exists for a single QTL for fat percentage; however, like DF, the single QTL location was estimated in a different location than either of the locations in the QTL model. Akaike's (1974) information content supports the single QTL model in this case.
Zhang et al. (1988) studied a large outbred pedigree of dairy cattle and identified QTL affecting milk fat yield and fat percentage on BTA27 that exceeded the chromosome-wise significance threshold. Results from that study placed a putative fat percentage QTL between markers CA209 and BM1857, corresponding to the same region where we have identified a QTL for the same trait in family 2. Results from that study also placed a putative fat yield QTL between markers BM1857 and BM203. This region corresponds to one of those identified for fat yield when 2 QTL were modeled in family 2. Casas et al. (2000) studied two large halfsib beef cattle families and identified putative QTL affecting marbling near marker BM17052, again corresponding to the same region where we have identified QTL affecting DF in family 8. Based on these results, uncertainty still exists about whether multiple QTL that affect different traits are segregating, or if only a few QTL exist with pleiotropic effects. Work is underway to develop complex, multi-generation pedigrees from these 2 original DBDR grandsires that will be genotyped and exploited in more sophisticated analyses to refine the QTL intervals and help clarify these issues.

\section{CONCLUSIONS}

Previously identified BTA27 marker associations for the DF conformation trait in 2 grandsire families of the DBDR were investigated further. Additional markers positioned on BTA27 were tested and analyzed. Interval analyses of BTA27 were completed in these families. For family 8, results indicate a QTL near BM203, with a broad confidence interval. Evidence exists for a milk, fat, and protein yield QTL segregating in this family in a different region of BTA27. In family 2, interval analyses suggest that one or two QTL may be present in the center of the chromosome. Stong evidence also exists for a QTL affecting fat percentage in this same 
family in a similar region as DF. In both families examined, the locations supporting QTL for DF have little or no effect on yield traits. These results suggest that the QTL may be useful for selecting animals that are more robust to metabolic disorders without forfeiting substantial genetic improvement in production traits. Efforts are underway to add informative markers in these regions and to extend the animals with genotypic data to include more recent descendents of these bulls. Also, analysis methods are being developed that properly incorporate the complex pedigrees to further refine locations of these putative QTL.

\section{ACKNOWLEDGMENTS}

We thank Tom Lawlor and Bert Klei (Holstein Association USA) for providing trait data on conformation traits. We thank the members of regional project NC209 and the contributing AI organizations for initiating, maintaining, and contributing to the Dairy Bull DNA Repository. We also thank Tina Sphon and Larry Shade for technical assistance.

\section{REFERENCES}

Akaike, H. 1974. A new look at the statistical model identification. IEEE Trans. Auto. Contr. AC-19:716-723.

Ashwell, M. S., Y. Da, P. M. VanRaden, C. E. J. Rexroad, and R. H. Miller. 1998. Detection of putative loci affecting conformational type traits in an elite population of United States Holsteins using microsatellite markers. J. Dairy Sci. 81:1120-1125.

Ashwell, M. S., C. E. J. Rexroad, R. H. Miller, and P. M. VanRaden. 1996. Mapping economic trait loci for somatic cell score in Holstein cattle using microsatellite markers and selective genotyping. Anim. Genet. 27:235-242.

Ashwell, M. S., C. E. J. Rexroad, R. H. Miller, P. M. VanRaden, and Y. Da. 1997. Detection of loci affecting milk production and health traits in an elite US Holstein population using microsatellite markers. Anim. Genet. 28:216-222.

Ashwell, M. S., C. P. Van Tassell, and T. S. Sonstegard. 2001. A genome scan to identify quantitative trait loci affecting economically important traits in a US Holstein population. J. Dairy Sci. 84:2535-2542.

Barendse, W., S. M. Armitage, L. M. Kossarek, A. Shalom, B. W. Kirkpatrick, A. M. Ryan, D. Clayton, L. Li, H. K. Neilbergs, N. Zhang, W. M. Grosse, J. Weiss, P. Creighton, F. McCarthy, M. Ron, A. J. Teale, R. Fries, R. A. McGraw, S. S. Moore, M. Georges, M. Soller, J. E. Womack, and D. J. S. Hetzel. 1994. A genetic linkage map of the bovine genome. Nat. Genet. 6:227-235.

Barendse, W., D. Vaiman, S. J. Kemp, Y. Sugimoto, S. M. Armitage, J. L. Williams, H. S. Sun, A. Eggen, M. Agaba, S. A. Aleyasin, M. Band, M. D. Bishop, J. Buitkamp, K. Byrne, F. Collins, L. Cooper, W. Coppettiers, B. Denys, R. D. Drinkwater, K. Easterday, C. Elduque, S. Ennis, G. Erhardt, L. Li, and L. Lil. 1997. A medium-density genetic linkage map of the bovine genome. Mamm. Genome 8:21-28.
Bishop, M. D., S. M. Kappes, J. W. Keele, R. W. Stone, S. L. F. Sunden, G. A. Hawkins, S. S. Toldo, R. Fries, M. D. Grosz, J. Yoo, and C. W. Beattie. 1994. A genetic linkage map for cattle. Genetics 136:619-639.

Casas, E., S. D. Shackelford, J. W. Keele, R. T. Stone, S. M. Kappes, and M. Koohmaraie. 2000. Quantitative trait loci affecting growth and carcass composition of cattle segregating alternate forms of myostatin. J. Anim. Sci. 78:560-569.

Casas, E., T. S. Sonstegard, W. Barendse, G. L. Bennett, C. D. Bottema, A. Crawford, M. D. Grosz, E. Kalm, S. M. Kappes, A. Kister, Y. Li, S. Lien, C. A. Morris, I. Olsaker, W. S. Pitchford, S. M. Schmutz, H. Thomsen, and N. Xu. 2001. Comprehensive linkage map of bovine chromosome 27. Anim. Genet. 32:95-97.

Da, Y., M. Ron, A. Yanai, M. Band, R. E. Everts, D. W. Heyen, J. I. Weller, G. R. Wiggans, and H. A. Lewin. 1994. The dairy bull DNA repository: A resource for mapping quantitative trait loci. Proc. 5th World Congr. Genet. Appl. Livest. Prod., Guelph, Canada 21:229-232.

Eberhart, R. J., R. J. Harmon, D. E. Jasper, R. P. Natzke, S. C. Nickerson, J. K. Reneau, E. H. Row, K. L. Smith, and S. B. Spencer. 1987. Current topics of bovine mastitis. National Mastitis Council, Arlington, VA.

Green, P., K. F. Falls, and S. Crooks. 1990. CRI-MAP Documentation, version 2.4. Online. Available: http://linkage.rockefeller.edu/soft/ crimap/. Accessed Apr. 3, 2003.

Haley, C. S., and S. A. Knott. 1992. A simple regression method for mapping quantitative trait loci in line crosses using flanking markers. Heredity 69:315-324.

Holstein Association USA. 2003. Holstein Type-Production Sire Summaries. February 2003. Holstein Assoc. USA, Brattleboro, VT.

Kappes, S. M., J. W. Keele, R. T. Stone, R. A. McGraw, T. S. Sonstegard, T. P. Smith, N. L. Lopez-Corrales, and C. W. Beattie. 1997. A second-generation linkage map of the bovine genome. Genome Res. 7:235-249.

Lander, E. S., and P. Green. 1987. Construction of multilocus genetic linkage maps in humans. Proc. Natl. Acad. Sci. USA 84:23632367.

Misztal, I., K. A. Weigel, and T. J. Lawlor. 1995. Approximation of estimates of (co)variance components with multiple-trait restricted maximum likelihood by multiple diagonalization for more than one random effect. J. Dairy Sci. 78:1862-1872.

Rogers, G. W., G. Banos, and U. Sander-Nielsen. 1999. Genetic correlations among protein yield, productive life, and type traits from the Untied States and diseases other than mastitis from Denmark and Sweden. J. Dairy Sci. 82:1331-1338.

Seaton, G., C. S. Haley, S. A. Knott, M. Kearsey, and P. M. Visscher. 2002. QTL Express: mapping quantitative trait loci in simple and complex pedigrees. Bioinformatics 18:339-340.

Sonstegard, T. S., W. M. Garrett, M. S. Ashwell, G. L. Bennett, S. M. Kappes, and C. P. Van Tassell. 2000. Comparative map alignment of BTA27 and HSA4 and 8 to identify conserved segments of genome containing fat deposition QTL. Mamm. Genome 11:682-688.

Van Tassell, C. P., M. S. Ashwell, and T. S. Sonstegard. 2000. Detection of putative loci affecting milk, health, and conformation traits in a US Holstein population using 105 microsatellite markers. J. Dairy Sci. 83:1865-1872.

Zhang, Q., D. Boichard, I. Hoeschele, C. Ernst, A. Eggen, B. Murkve, M. Pfister-Genskow, L. A. Witte, F. E. Grignola, P. Uimari, G. Thaller, and M. D. Bishop. 1998. Mapping quantitative trait loci for milk production and health of dairy cattle in a large outbred pedigree. Genetics 149:1959-1973. 